\title{
Survival of Douglas-fir provenances in Austria: site-specific late and early frost events are more important than provenance origin
}

\author{
Debojyoti Chakraborty $^{1}$ (D) $\cdot$ Christoph Matulla $^{2} \cdot$ Konrad Andre $^{2} \cdot$ Lambert Weissenbacher $^{1} \cdot$ Silvio Schueler $^{1}$
}

Received: 21 January 2019 / Accepted: 1 September 2019 / Published online: 29 October 2019

(C) INRA and Springer-Verlag France SAS, part of Springer Nature 2019

\begin{abstract}
- Key message Autumn and spring frost events caused wide variation in the survival of juvenile Douglas-fir in Austrian forest sites located in the transition zone from Atlantic to continental climate. Survival rate can be optimized by planting provenances originating from an altitudinal belt of 500-1400 $\mathrm{m}$ in North America. Neither the variety nor the climate of origin of planted Douglas-fir provenances influence its response to frost events.

- Context Understanding the risks of frost during late spring and early autumn is crucial for planting non-native Douglas-fir (Pseudotsuga menziesii [Mirbel] Franco) as an alternative tree species under climate change in Europe.

- Aims We investigate the role of early and late frost events on the survival of juvenile Douglas-fir and tested whether survival depends on seed origin.

- Methods With data from 19 provenance trials across Austria, we modeled the effects of early and late frost events on juvenile survival rate, accounting for random variations due to site condition and provenance origin.

- Results Wide variations (37-93\%) in the juvenile survival rate of Douglas-fir were mainly driven by early and late frost events (daily $\mathrm{T}_{\min }<0{ }^{\circ} \mathrm{C}$ ), summer drought, and continentality. Juvenile survival declined with an increasing number of frost events within the observation period and prevailing warm spells preceding the frost events. The seed origin of the tested provenances had a minor effect and was related to the altitude, but not to the variety or the climate of provenance origin.

- Conclusion For planting Douglas-fir in the transition zone from Atlantic to continental climates, typical in Austrian forests, the local site conditions and the probability of the occurrence of early and late frosts should be considered, while provenance selection should rather focus on productivity.
\end{abstract}

Keywords Climate change $\cdot$ Pseudotsuga menziesii $\cdot$ Provenance trial $\cdot$ Extreme events $\cdot$ Early frost $\cdot$ Late frost $\cdot$ Survival

\section{Introduction}

Handling Editor: Andreas Bolte

Contribution of the co-authors DC: did the analysis and wrote the manuscript, CM \& KA: provided climate data, LW: performed measurement of provenance trials and recorded observations, SS: conceived the research, reviewed analysis and manuscript

This article is part of the topical collection on Forest Adaptation and Restoration under Global Change

Debojyoti Chakraborty

debojyoti.chakraborty@bfw.gv.at

1 Austrian Research Centre for Forests (BFW), Vienna, Austria

2 Climate Impact Team, Climate Research Branch, Zentralanstalt für Meteorologie und Geodynamik, Vienna, Austria
Decades of scientific research have provided convincing evidence of observed and likely impacts of human-induced climate change on forests, necessitating substantial adaptation measures. In Europe, the effects of climate change on forests may include changes in forest productivity (Reyer et al. 2014), changes in tree species distributions and their economic value (Hanewinkel et al. 2013), effects of intensifying disturbance regimes (Seidl et al. 2017), and droughts (Allen et al. 2010). Adaptive management aiming at reducing vulnerability and enhancing the resilience of forest ecosystems is a key to preserve the potential of forests to provide multiple ecosystem services under climate change. Conifer forests in lower elevations of Central Europe are often dominated by secondary Norway spruce (Picea abies [L.] Karst) and can be considered 
as a classical example of forests vulnerable to climate change. A drastic decline in productivity and abundance accompanied by the higher risk of windthrow and bark beetle attack is expected in such forests (Klimo and Hager 2000; Bolte et al. 2009; Lindner et al. 2010; Seidl et al. 2011; Spiecker et al. 2012). Adaptive management may also include changing the structure and composition of vulnerable forests by planting alternative species which may include non-native tree species adapted to expected future climatic conditions (Bolte et al. 2009; Lindner et al. 2010; Spiecker et al. 2012). The North American Douglas-fir (Pseudotsuga menziesii [Mirbel] Franco) is one such alternative tree species currently under consideration in Europe because of its excellent growth performance, wood quality, and its tolerance of drought and pests.

Intraspecific variation in phenotypic traits and demographic processes such as mortality and survival need to be examined before prescribing alternative tree species and provenances for planting. Tree mortality is an important demographic process in forest ecosystems. Major causes of tree mortality are competition for limited resources such as light and water (MullerLandau et al. 2006; Allen et al. 2010), disturbances such as pest outbreak and wind (Westerling et al. 2006; Van Mantgem et al. 2009; Senf et al. 2018), age, size- and density-related factors (He and Duncan 2000; Cruickshank 2017), and abrupt deviation from mean weather conditions such as spring and autumn frosts (Neumann et al. 2017). Although Douglas-fir is known to tolerate winter temperatures as low as $-80{ }^{\circ} \mathrm{C}$ (Sakai and Weiser 1973), extreme temperature variations such as shortterm spring and autumn frost events are known to cause damage and mortality of Douglas-fir, both in North America (Day and Chrystal 1928; Foster and Johnson 1963; Simpson 1990; Kreyling et al. 2014; Bansal et al. 2015) and Europe (Larsen 1978; Schmiedel 1981; Braun and Scheumann 1989; Braun and Wolf 2001); Sychra and Mauer 2013).

Frost tolerance in perennial temperate plants is a triphasic phenomenon whereby plants undergo hardening during the autumn, dormancy during winter, and dehardening as spring approaches (Glerum 1985). Abrupt fluctuations of temperature and occurrence of extremely low temperature during the hardening and dehardening process cause stress which may manifest itself in cell injury or death of affected tree organs or even the complete tree (Coder et al. 2011). Bud break and subsequent effects of frost on temperate trees are regulated by a complex interaction of photoperiod, temperature, and genetics (e.g., Schueler and Liesebach 2014). Under global warming, photoperiod is unlikely to change, while temperature extremes such as extremely low temperature during fall and spring are still expected to occur (IPCC 2013). The combined influence of lengthened growing season, warmer winter, and spring temperatures already resulted in advanced spring phenological development (Scheifinger et al. 2003; Fu et al. 2014). This phenomenon is likely to be accompanied by increased temperature variability (Liu et al. 2018) presenting levels of cold stress, which are higher than a conifer species is genetically programmed to tolerate (Beck et al. 2004; Bansal et al. 2015).

Owing to its wide geographic range, Douglas-fir exhibits strong intraspecific variations in its ability to tolerate extremely low temperatures (O'Neill et al. 2001; St Clair 2006). The interior or the Rocky mountain provenances are known to have a higher tolerance to frost, compared to the coastal provenances (Stevenson et al. 1999; O'Neill et al. 2001; St Clair 2006; Bansal et al. 2015; Kreyling et al. 2015; Malmqvist et al. 2017).

In Europe, Douglas-fir has been widely studied in the context of productivity or growth performance where modeling studies suggested that interior provenances could be more suitable for continental and northern Europe (Isaac-Renton et al. 2014), while experimental studies found that coastal provenances outperform interior ones under a wide range of environmental conditions (Konnert and Ruetz 2006; Kölling 2008; Petkova 2011; Chakraborty et al. 2015). However, studies on frost tolerance of Douglas-fir in Europe are rare (Malmqvist et al. 2017). Moreover, the majority of the studies on the effects of frost on conifers are based on visual inspection of the damage to tissues or plant parts exposed to artificially regulated low temperatures in programmable freezers. Therefore, these studies cannot mimic the abrupt changes in weather conditions as well as confounding factors such as shade and competition expected in nature (St Clair 2006; Bansal et al. 2015). Apart from this, majority of the studies use long-term average climatic variables such as mean coldest month temperature to quantify the effects of climate on frost damage which obviously does not represent the extreme variations in low temperature on a daily basis which are the actual cause of frost-related damage (Beck et al. 2004; Strimbeck et al. 2015).

The success of active adaptive management strategies such as planting non-natives will require precise knowledge about the intraspecific variations in multiple functional traits such as productivity, survival, cold hardiness, and the trade-offs therein (Bolte et al. 2009; Lindner et al. 2010). Therefore, it is crucial to identify those provenances of Douglas-fir which not only have superior growth performance but also cold and drought tolerance. Common garden tests or provenance trials provide excellent opportunities to examine how different seed sources differ in their ability to withstand low temperatures as a result of climateinduced natural selection (St Clair 2006; Kreyling et al. 2015).

We aim to test if Douglas-fir in Austria is adapted to extreme climate events within the vegetation period such as early and late frost and examine the role of provenance origin in driving frost tolerance. We not only identify and quantify the effect size of specific parameters that characterize early and late frost event but also consider annual and seasonal climate descriptors of the trial plantation (temperature, precipitation, and drought) and tree age on the survival of juvenile Douglasfir. Furthermore, we examined whether provenance origin influences the effects of such drivers and recommend provenances with optimum survival rates for our study area. 


\section{Materials and methods}

\subsection{Provenance trials}

In the present study, we investigated the role of extreme events (early and late frost) on the survival rate of 160 North American Douglas-fir provenances planted across 19 provenance trials in Austria (Chakraborty et al. 2018). These trials were established between 1973 and 1993 by the Austrian Research Centre for Forests (BFW, Vienna) across a wide spectrum of site conditions (Fig. 1). All seed sources originate from western North America and were collected during the international IUFRO collection 1967/68 and during German and Austrian seed collection from North America in the 1970s (Schultze and Raschka 2002). The provenance trials were designed as randomized blocks. Within each block (replication), three to four-year-old pre-cultivated seedlings of selected provenances were planted in plots of 20-100 individuals with a spacing of $2 \mathrm{~m} \times 2 \mathrm{~m}$. The number of alive and dead trees/ seedlings was recorded for each trial between trial ages 3 and 10 years before any management measures on the trials were implemented. Since 3-4-year-old seedlings were planted, the actual tree ages correspond to $6-14$ years when they were inventoried. For trials with survival records in multiple years, we used the latest assessment to calculate the survival rate. Survival rate was calculated as the proportion of surviving individuals by the total number of trees of each provenance in each trial calculated as follows (Eq. 1):

Survival rate $=\frac{\mathrm{A}_{i j}}{\mathrm{~N}_{i j}}$

where $\mathrm{A}_{i j}$ is the number of alive trees of $i$ th provenance in $j$ th planting site and $\mathrm{N}_{i j}$ is the total number of trees of $i^{\text {th }}$ provenance in the $j^{\text {th }}$ planting site.

Since not all provenances were planted in each trial, they were grouped into clusters, (i) four clusters based on the climatic conditions of the provenance origin; (ii) three clusters based on the variety, respectively phylogeographic origin of provenances, whereby the provenances were grouped into the interior and coastal variety and the coastal variety was further divided into coastal and cascade provenances, accounting also for the adaptive variations within the coastal variety according to (Rehfeldt et al. (2014);

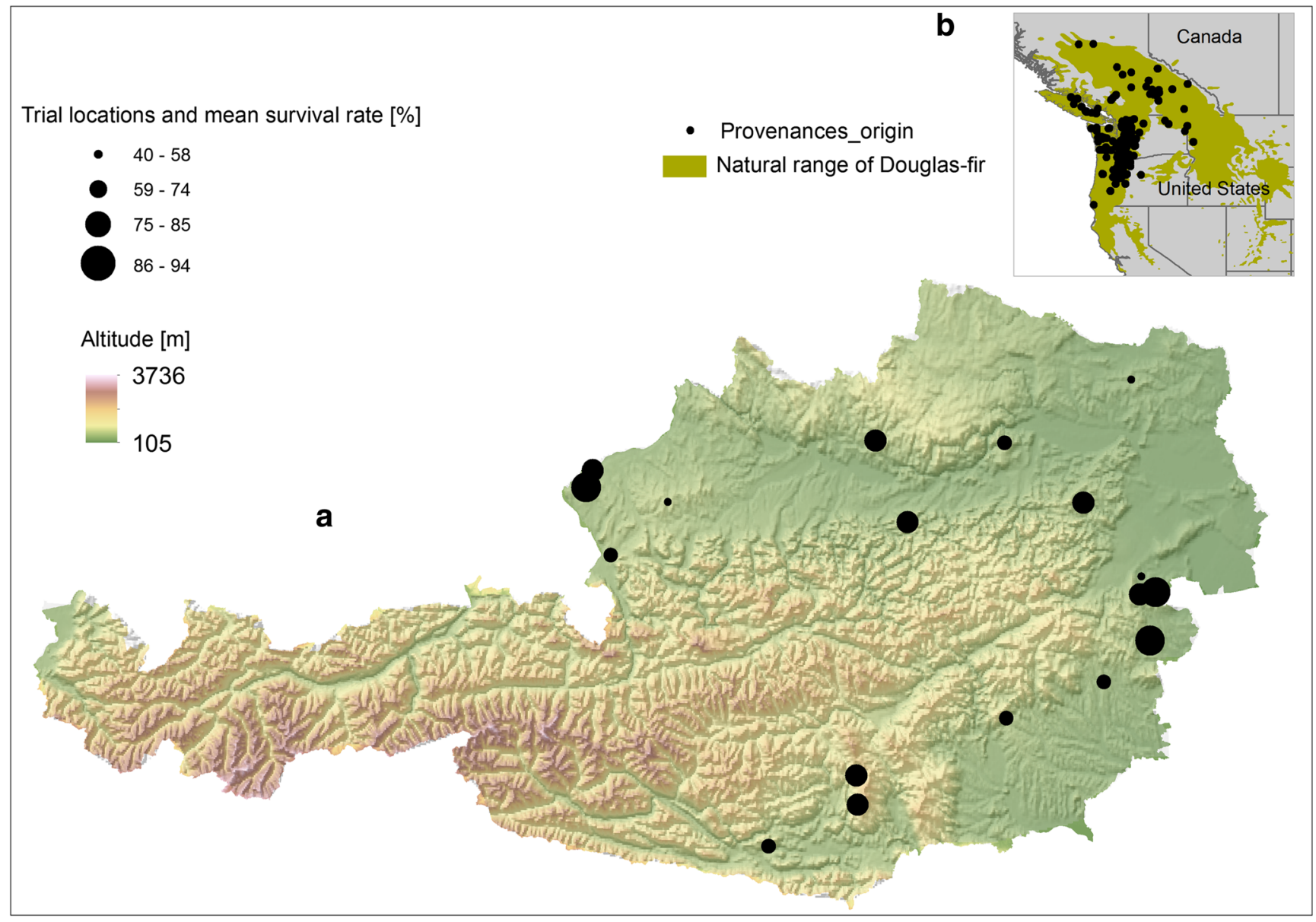

Fig. 1 Location of the analyzed Douglas-fir provenance trials in Austria (A) including their mean juvenile survival rate across all provenances. Locations of provenance origin in Northwestern North America planted in the Austrian trials (B) 
(iii), three altitudinal clusters $(0-500,500-1000$, and 1000-1400 m) (Fig. 7 Annex).

The four climatic clusters were developed following Kapeller et al. (2012), whereby a principal component analysis with the provenance climate defined by 20 climatic variables of provenance origin (Table 1) was performed in a first step. The 20 annual and seasonal climate variables for each provenance origin were generated using the high-resolution climate model Climate WNA v4.72 (Wang et al. 2012) for the period 1961-1990. The first four principal components (accounting for $97 \%$ of the variance in the data) were then used in the clustering routine "partitioning around medoids" in R-package cluster (Maechler et al. 2015) to create four climatic clusters.

\subsection{Climate data}

Daily mean, minimum, and maximum temperature and precipitation sums were provided by the Central Institute for Meteorology and Geodynamics (ZAMG), Vienna, Austria for each provenance trial site for the duration between the trial establishment and the latest juvenile inventory, referred to as inventory period (Table 4 in Annex). These climate data are based on observations from weather stations, which were interpolated to the coordinates of the trial sites by altitudinal adjusting and inverse distance weighted interpolation (see Chakraborty et al. 2015 for details). From this daily time series, 20 climatic extreme variables describing early and late frost events and 20 annual and seasonal climate variables were calculated (Table 1). The extreme climate variables describe the frequency and severity of frost events, for example, the number of days with late or early frost events in the inventory period, the absolute minimum temperature of late frost events within the inventory period, and also parameters that consider the weather conditions preceding a given extreme event, such as the temperature difference between the absolute minimum temperature of the preceding day or the number of vegetation days with mean daily temperatures above $5{ }^{\circ} \mathrm{C}$ between 1 January and the absolute minimum temperature (Fig. 8 in Annex). Frost events refer to a daily minimum temperature below $0{ }^{\circ} \mathrm{C}$. In this study, we considered frost events in May and June as late or spring frost events and those occurring in the months of July, August, and September as early or autumn frost events outside actual winter (November-February). The annual and seasonal variables describe the mean weather conditions of the trial sites within the inventory period (Table 1).

\subsection{Variable selection}

From the list of potential predictor variables (Table 1), the most important ones were selected with a recursive feature elimination approach (RFE) implemented within the Random forest algorithm (Breiman 2001). Within the RFE approach, variables were eliminated iteratively, starting from the full set of potential predictors (Table 1), and retaining only those variables (Tables 2 and 3) that reduce the mean square error over random permutations of the same variable. The variables which were linearly correlated with other variables and had variance inflation factors VIF $>5$ were identified and the ones with the lower value according to the Akaike Information Criteria (AIC) (Akaike 1974) were retained for further model development. This subset of uncorrelated climate variables, and their interactions, were used as predictor variables to model the juvenile survival rate in the GLMM and the GLM. Model simplification was done with all-subset approach implemented with the leaps package (Lumley 2009) in $R$ statistical software (R Core Team 2013).

\subsection{Statistical analysis}

Generalized linear mixed model (GLMM) with a logit link was used to analyze the effects of extreme climatic drivers (early and late frost events), and annual and seasonal climate variables on the survival rate of juvenile Douglas-fir (up to 14 years). The juvenile survival rate was the dependent variable. Parameters describing early and late frost events, their interactions, the annual and seasonal climate descriptors and demographic variable such as tree age were used as fixed effects, while provenance origin, planting location, and the interaction between provenance and planting location were considered as random effects (Eq. 2):

$$
\begin{aligned}
Y_{i j k}= & \beta_{0}+\alpha_{1} C_{1 j k k}+\alpha_{2} C_{2 i j k}+\cdots \alpha_{n} C_{n i j k} \\
& +\alpha_{n 1 i j k} C_{1} * C_{2}+b_{1 i j} \text { Provenance } \\
& +b_{2 i k} \text { Site }+b_{3 i j k} \text { Site*Provenance }+e_{i j k}
\end{aligned}
$$

Where, $Y_{i j k}$ is the survival rate (\%) of the $i$ th tree of the $j$ th provenance at the $k$ th planting location; $\beta_{0}$ is the intercept; $\alpha_{1}$ to $\alpha_{n}$ are the fixed effects, $b_{1}$ to $b_{3}$ the random effects, and e is the residual error. $C_{1}, C_{2} \ldots C_{n}$ represent the selected site climate variables defining early and late frost and mean climate conditions. Random effects accounted for sources of variation not explained by the fixed effects and captured by the experimental design such as planting location and provenance origin.

In order to identify attributes of provenance origin that likely influence the role of early and late frost events and seasonal climate on juvenile survival rates, generalized linear models (GLM) with a logit link was developed with only the fixed effects of (Eq. 2), whereas attributes describing the provenance origin were added as covariates (Eq. 3). Also in the 
Table 1 List of climate variables calculated to describe frost events $\left(\mathrm{T}_{\min }<0{ }^{\circ} \mathrm{C}\right)$, the weather conditions surrounding frost events occurring outside winter months (Nov-Feb), and annual and seasonal variables that describe the climate of the trial sites

\begin{tabular}{|c|c|}
\hline Acronym & Explanation of the variable \\
\hline \multicolumn{2}{|c|}{ Extreme climate variable: late frost (May-June) } \\
\hline LF1 & Number of late frost days with daily minimum temperatures $<0{ }^{\circ} \mathrm{C}$ \\
\hline LF3 & Absolute late frost temperature minimum \\
\hline LF4 & Mean temperature of the day on which LF3 occurred \\
\hline LF5 & Maximum number of late frost events within a single year within the inventory period \\
\hline LF6 & Sum of precipitation across the seven 7 days before LF3 occurred \\
\hline LF7 & Number of vegetation days $>5^{\circ} \mathrm{C}$ from 1 . January until LF3 \\
\hline LF8 & Number of vegetation days $>10^{\circ} \mathrm{C}$ from 1 . January until LF3 \\
\hline LF9 & Temperature difference between LF3 date and the minimum temperature of the preceding day \\
\hline LF10 & Temperature difference between LF3 date and the mean temperature of the preceding day \\
\hline LF11 & Temperature difference between LF3 date and the minimum temperature of the seven preceding days \\
\hline LF12 & Temperature difference between LF3 date and the mean temperature of the seven preceding days \\
\hline \multicolumn{2}{|c|}{ Extreme climate variable: early frost (July-Sep) } \\
\hline EF1 & Number of early frost days with daily minimum temperatures $<0{ }^{\circ} \mathrm{C}$ \\
\hline EF3 & Absolute early frost temperature minimum \\
\hline EF4 & Mean temperature of the day on which EF3 occurred \\
\hline EF5 & Maximum number of late frost events within a single year within the inventory period \\
\hline EF6 & Sum of precipitation across the seven 7 days before EF3 occurred \\
\hline EF7 & Number of vegetation days $>5^{\circ} \mathrm{C}$ from 1 . January until EF3 \\
\hline EF8 & Number of vegetation days $>10^{\circ} \mathrm{C}$ from 1 . January until $\mathrm{EF} 3$ \\
\hline EF9 & Temperature difference between EF3 date and the minimum temperature of the preceding day \\
\hline EF10 & Temperature difference between EF3 date and the mean temperature of the preceding day \\
\hline EF11 & Temperature difference between $\mathrm{EF} 3$ date and the minimum temperature of the seven preceding days \\
\hline EF12 & Temperature difference between EF3 date and the mean temperature of the seven preceding days \\
\hline \multicolumn{2}{|c|}{ Seasonal and annual climate variables } \\
\hline MAT & Mean annual temperature $\left({ }^{\circ} \mathrm{C}\right)$ \\
\hline MWMT & Mean warmest month temperature $\left({ }^{\circ} \mathrm{C}\right)$ \\
\hline MCMT & Mean coldest month temperature $\left({ }^{\circ} \mathrm{C}\right)$ \\
\hline $\mathrm{TD}$ & Continentality, i.e. temperature difference between MWMT and MCMT $\left({ }^{\circ} \mathrm{C}\right)$ \\
\hline MAP & Mean annual precipitation $(\mathrm{mm})$ \\
\hline MSP & Mean summer (May to Sept.) precipitation (mm) \\
\hline AHM & Annual heat: moisture index $(\mathrm{MAT}+10) /(\mathrm{MAP} / 1000))$ \\
\hline SHM & Summer heat: moisture index ((MWMT)/(MSP/1000)) \\
\hline $\mathrm{DD}<0$ & Degree-days below $0{ }^{\circ} \mathrm{C}$, chilling degree-days \\
\hline $\mathrm{DD}>5$ & Degree-days above $5{ }^{\circ} \mathrm{C}$, growing degree-days \\
\hline $\mathrm{DD}<18$ & Degree-days below $18^{\circ} \mathrm{C}$, heating degree-days \\
\hline $\mathrm{DD}>18$ & Degree-days above $18^{\circ} \mathrm{C}$, cooling degree-days \\
\hline NFFD & The number of frost-free days \\
\hline FFP & Frost-free period \\
\hline bFFP & The Julian date on which FFP begins \\
\hline eFFP & The Julian date on which FFP ends \\
\hline PAS & Precipitation as snow $(\mathrm{mm})$ between August in previous year and July in current year \\
\hline EMT & Extreme minimum temperature over 30 years \\
\hline Eref & Hargreaves reference evaporation \\
\hline CMD & Hargreaves climatic moisture deficit \\
\hline \multicolumn{2}{|c|}{ Demographic factor } \\
\hline Tree age & Age of the surviving trees of a given provenance at a given planting site \\
\hline
\end{tabular}

Early Frost (EF) relates to frost events occurring toward the end of the vegetation period between July and September and late frost (LF) relates to frost events at the beginning of the vegetation period in May and June. All climate variables were calculated with respect to the inventory period of a given field trial, thus referring from trial establishment until the next mortality assessment made up to trial ages of 10 years. Due to different trial establishment years and differences in the age of mortality assessments, the lengths of the inventory periods differ among trials. An explanation of the calculation is available in Fig. 8 in Annex. In addition, a non-climatic factor tree density is also included. The annual and seasonal variables were also calculated at the locations of provenance origin in North America 
Table 2 Results of the generalized linear mixed model (GLLM) showing the fixed effects of the climate variables describing early and late frost events, tree age, and the mean climate conditions and the random effects of the site (planting location) provenance or seed origin and tree age and their interactions on the juvenile survival rate of Douglas-fir

\begin{tabular}{|c|c|c|c|c|c|c|}
\hline Effect type & Driver type & Drivers & Estimate & Std. Error & $Z$ value & $P$ value \\
\hline & & Intercept & 3.85 & 0.410 & 3.654 & 0.009 \\
\hline \multirow[t]{11}{*}{ Fixed effects } & Late frost & $\mathrm{LF} 1$ & -0.37 & 0.224 & -4.168 & 0.008 \\
\hline & & LF8 & -0.134 & 0.335 & -7.401 & 0.006 \\
\hline & & LF12 & -1.064 & 0.526 & -4.421 & 0.006 \\
\hline & Early frost & EF1 & -8.225 & 0.388 & -5.981 & 0.032 \\
\hline & & EF4 & -2.712 & 0.328 & -2.815 & 0.004 \\
\hline & & EF7 & -0.219 & 0.189 & -4.163 & 0.002 \\
\hline & LF-EF Interaction & LF1 x EF1 & -0.747 & 1.192 & 4.627 & 0.050 \\
\hline & Mean climate & $\mathrm{TD}$ & -0.245 & 0.267 & -6.917 & 0.000 \\
\hline & & SHM & 1.795 & 1.8386 & 6.977 & 0.000 \\
\hline & Demographic & Tree age & -0.015 & 0.210 & -0.073 & 0.150 \\
\hline & & & Variance & St. dev & & \\
\hline \multirow[t]{3}{*}{ Random effects } & & Planting location & 0.0067 & 0.082 & & 0.272 \\
\hline & & Provenance origin & 0.0011 & 0.033 & & 0.415 \\
\hline & & Planting location $\mathrm{x}$ provenance origin & 0.0001 & 0.010 & & 0.514 \\
\hline
\end{tabular}

$R^{2}$ adjusted (fixed effects) 0.640

$R^{2}$ adjusted (fixed + random effects) 0.642

For an explanation of the acronyms of the variables see Table 1

GLM, the juvenile survival rate was used as the dependent variable.

$$
\begin{aligned}
Y_{i j k}= & \beta_{0}+\alpha_{1} C_{1 i j k}+\alpha_{2} C_{2 i j k}+\cdots \alpha_{n} C_{n i j k} \\
& +\alpha_{n 1 i j k} C_{1} * C_{2}+b_{1} \text { Climatic cluster } \\
& +b_{2} \text { Variety }+b_{3} \text { Altitude }+e_{i j k}
\end{aligned}
$$

Here, $Y_{i j k}$ is the survival rate $(\%)$ of the $i$ th tree of the $j$ th provenance at the $k$ th planting location; $\beta_{0}$ is the intercept; $\alpha_{1}$ to $\alpha_{\mathrm{n}}$ are the coefficients of the site climate variables; $\mathrm{C}_{1}$, $C_{2} \ldots C_{n}$ defining early and late frost and mean weather conditions; $b_{1}, b_{2}$, and $b_{3}$ the covariates of provenance origin attributes and $e$ is the residual error.

\section{Results}

\subsection{Effects of frost on the survival of Douglas-fir}

Mean survival rate of juvenile Douglas-fir trees varied significantly between provenance trials (Kruskal Wallis test; $p<0.000$ ) and range from 37 to $93 \%$, with a mean of $74.3 \%$ across all trials (Fig. 2). The GLMM explained around 64\% of the variation in juvenile survival rate (Table 2 ). The most important late or spring frost-related variables were the number of LF days (LF1), the temperature difference between absolute LF temperature minimum, and the mean temperature of the seven preceding days (LF12) and the number of vegetation days $>10^{\circ}$ until the absolute LF temperature minimum (LF8) (Table 2). Significant early, respectively autumn frost variables were the number of EF days (EF1), the daily mean temperature of the EF day with the absolute EF temperature minimum (EF4), and the number of vegetation days $>5^{\circ} \mathrm{C}$ until the absolute $\mathrm{EF}$ temperature minimum (EF7). The most important and significant climate variables describing the overall site climate were the summer heat moisture index SHM, which might be used to quantify xeric, but not necessarily drought conditions, and continentality, which is the difference between the warmest and coldest month temperature (Table 2).

In general, survival decreased with an increasing number of late and early frost days and with prevailing warmer conditions (vegetation days $5-10^{\circ} \mathrm{C}$ ) before the day of the respective extreme late or early frost event (Fig. 3; Table 2). The interaction between the number of early and late frost days was also found to be significant and positively influenced the survival rate (Table 2). This means that sites with an equal number of early and late frost events have a higher survival rate compared to sites where the number of early and late frost events differ. Increasing summer heat moisture index, where higher values describe conditions with higher temperatures and lower precipitation and thus more xeric conditions had a slightly positive effect on the survival rate, whereas survival declined with increasing continentality (Table 2 ). The fixed 
Table 3 Results of the generalized linear model (GLM) showing the effects of seed origin and the effects of the significant climate variables describing early and late frost events, the mean climate conditions of the trial sites and tree age on the juvenile survival rate of Douglas-fir

\begin{tabular}{|c|c|c|c|c|c|c|c|}
\hline Driver type & Drivers & Estimate & Std. error & $t$ value & $p$ value & Partial $R^{2}$ & Contribution to sum of partial $R^{2}$ \\
\hline & Intercept & 3.264 & 1.471 & 2.219 & $<0.00$ & & \\
\hline \multirow[t]{3}{*}{ Late frost } & LF1 & -0.101 & 0.052 & -1.956 & $<0.00$ & 0.18 & 9.92 \\
\hline & LF8 & -0.004 & 0.003 & -1.284 & $<0.00$ & 0.04 & 2.31 \\
\hline & LF12 & -0.159 & 0.043 & -3.659 & $<0.00$ & 0.74 & 41.04 \\
\hline \multirow[t]{3}{*}{ Early frost } & EF1 & -0.311 & 0.304 & -1.022 & $<0.00$ & 0.00 & 0.16 \\
\hline & $\mathrm{EF} 4$ & -0.118 & 0.037 & -3.214 & $<0.00$ & 0.57 & 31.48 \\
\hline & EF7 & -0.007 & 0.005 & -1.452 & $<0.00$ & 0.07 & 3.94 \\
\hline LF-EF interaction & $\mathrm{LF} 1 \times \mathrm{EF} 1$ & 0.023 & 0.002 & 0.843 & $<0.00$ & 0.00 & 0.10 \\
\hline \multirow[t]{2}{*}{ Mean climate } & $\mathrm{TD}$ & -0.005 & 0.002 & -1.160 & $<0.00$ & 0.02 & 1.24 \\
\hline & SHM & 0.045 & 0.020 & 1.100 & $<0.00$ & 0.01 & 0.75 \\
\hline Demographic & Tree age & -0.007 & 0.02 & -0.28 & 0.77 & 0.06 & 3.30 \\
\hline \multirow[t]{3}{*}{ Provenance origin } & 4.Climate cluster & -0.012 & 0.01 & -0.33 & 0.18 & 0.05 & 2.67 \\
\hline & 3. Altitude-zone cluster & 0.023 & 0.01 & 0.19 & $<0.00$ & 0.05 & 2.79 \\
\hline & 3. Seed-zone cluster & -0.02 & 0.02 & -0.22 & 0.22 & 0.01 & 0.29 \\
\hline
\end{tabular}

$R^{2}$ adjusted $=0.59$

For an explanation of the acronyms of the variables see Table 1. Partial $R^{2}$ refers to the change in the adjusted model $R^{2}$ when the respective variable is removed from the GLM. The percent contribution of a particular explanatory variable is calculated as the percentage of its partial $R^{2}$ over the sum of partial $R^{2}$ of all explanatory variables

effect of tree age and the random effects of provenance origin, planting locations, and the interaction between provenance origin and planting location were negligible (Table 2).

\subsection{Does seed origin matter?}

Seed origin was defined on the basis of climate, altitude, and variety of Douglas-fir in North America (Fig. 7 in Annex). The GLM which explained around $59 \%$ of the variation in juvenile survival rate suggests that survival rate slightly increased with an increasing altitude of the seed origin (Table 3, Fig. 4). Provenances originating from the mid (500-1000 m) and high (1000-1400 m) altitudinal levels had higher survival rates compared to those originating from low altitude $(0-500 \mathrm{~m})$ in most of the trials (Table 3 ). Other attributes of provenance origin such as the climate of provenance and variety were not found to be significant (Table 3, Fig. 5).

Provenances from the Cascade region of North America such as the Ashford Elbe, Randle, Darrington, Trout Lake, which are typically among the most productive seed sources
Fig. 2 Survival rates of juvenile Douglas-fir in 19 provenance trials in Austria. The horizontal line corresponds to the mean survival rate across all the trials $(74.3 \%)$. The $x$-axis represents the name of the trials

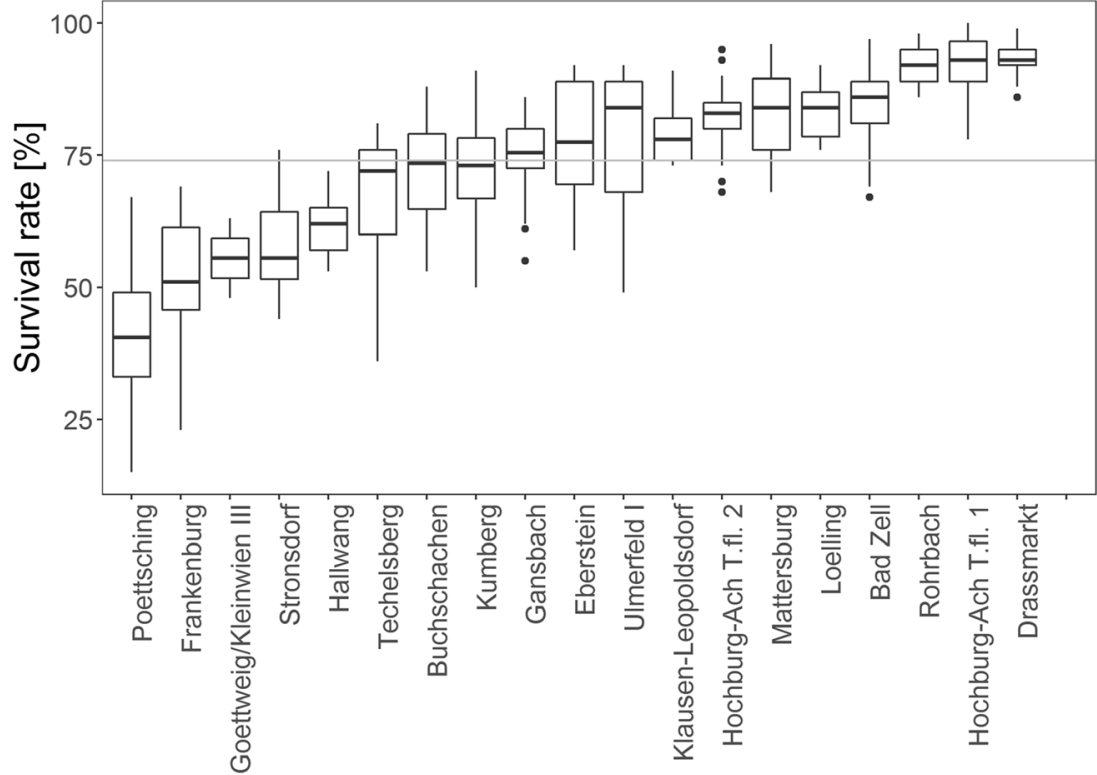




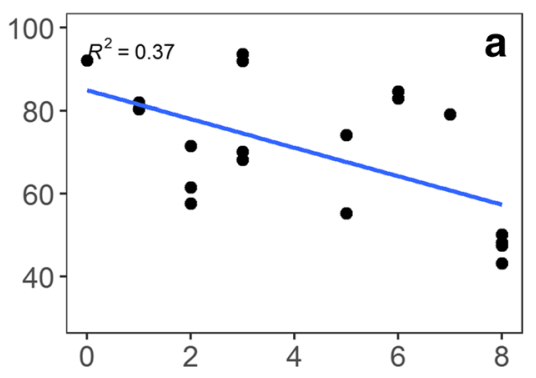

No of LF days (May-Jun) with daily $\operatorname{Tmin}<0^{\circ} \mathrm{C}(\mathrm{n})$

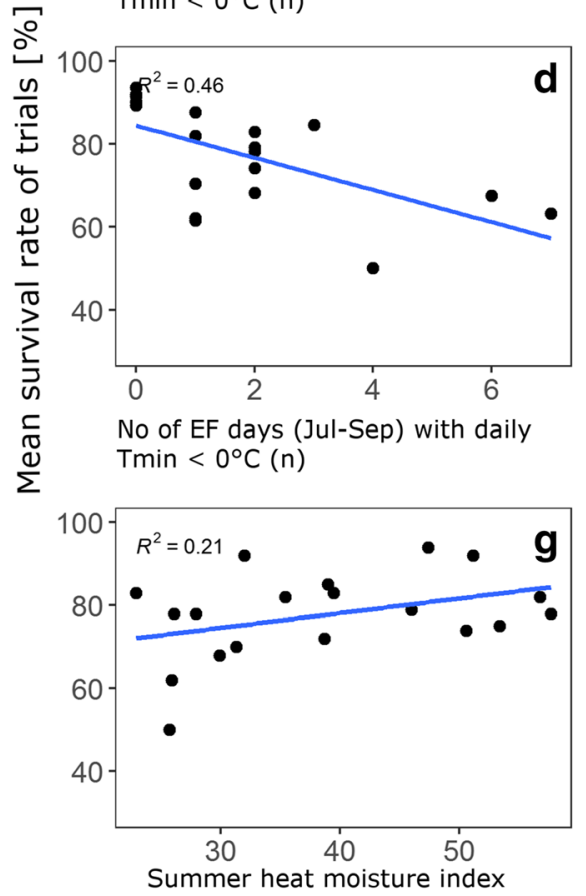

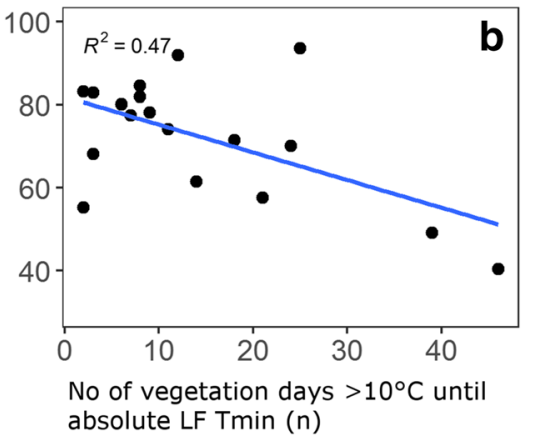

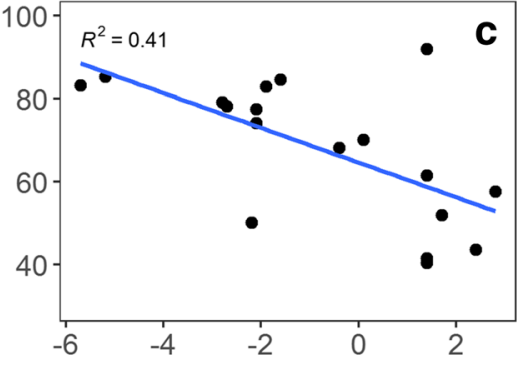

Temp difference between absolute LF Tmin and Tmean of 7 preeceding days $\left({ }^{\circ} \mathrm{C}\right)$

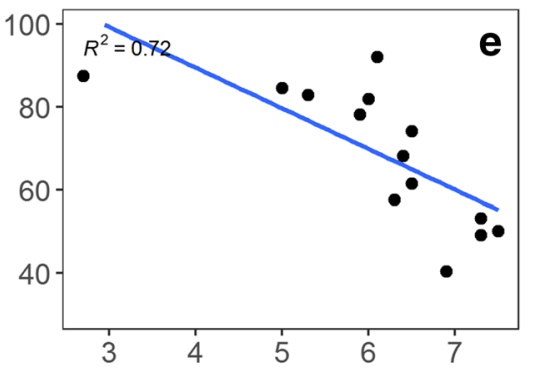

Tmean of EF day with absolute EF temperature minimum $\left({ }^{\circ} \mathrm{C}\right)$

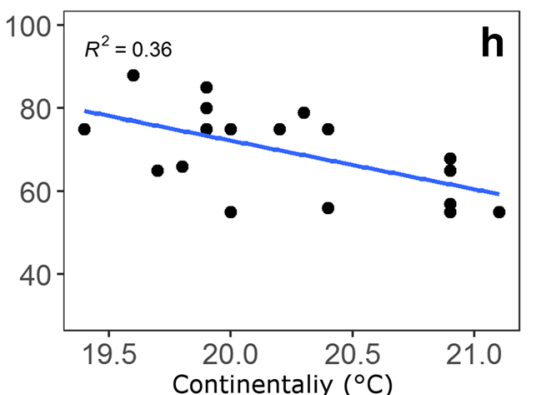

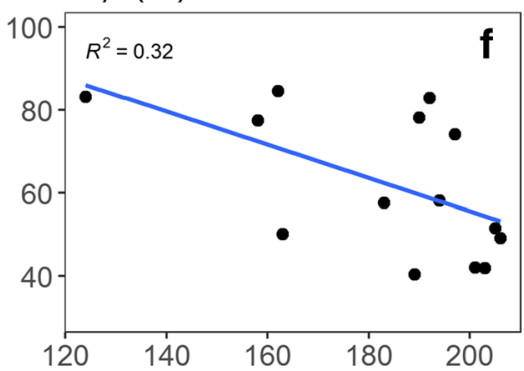

No of vegetation days $>5^{\circ} \mathrm{C}$ until absolute EF temperature minimum (n)

Fig. 3 Response of mean survival rate within trials as to the significant early and late frost variables as well as to mean climate descriptors (see Table 1 for details)

in European trials (Chakraborty et al. 2016) were generally also among the top three provenances in terms of survival in the majority of the trials (Fig. 6), though statistical differences in the survival rate of Douglas-fir provenances in terms of climate and variety were not detected. Only within a few trials in the continental East of Austria such as Pötsching, interior provenances from British Columbia such as Williams Lake, Adams Lake, and Owl Creek were among the top three surviving provenances.

\section{Discussion}

Planting non-native tree species as an adaptive management strategy under climate change will depend on the productivity of the introduced species and its contribution to the expected ecosystem services including economic and ecological values. Prerequisite for a successful utilization, however, is the interaction between potential environmental stress factors and the species' inherited adaptive traits. In temperate, alpine, and boreal forests, knowledge of intraspecific variation in early and late frost tolerance is a key factor for the selection of suitable planting material of Douglas-fir in Europe, where climate conditions were found to be non-analogous (IsaacRenton et al. 2014; Chakraborty et al. 2015) to its native range in North America.

The trials used in the present study represent a wide range of climate conditions from continental East to high altitude temperate conditions making the results of the study applicable across a wide range of conditions in Central Europe. The applied GLMM and GLM provided a reasonable model fit (Tables 2 and 3) and allowed identifying significant frostrelated stress factors as well as mean climate descriptors that influence the survival of juvenile Douglas-fir. Since the exact cause of mortality was not recorded in the analyzed trials, the juvenile survival rate could potentially also be attributed to some unknown climatic and non-climatic factors. However, the unspecified descriptors of the site conditions and 


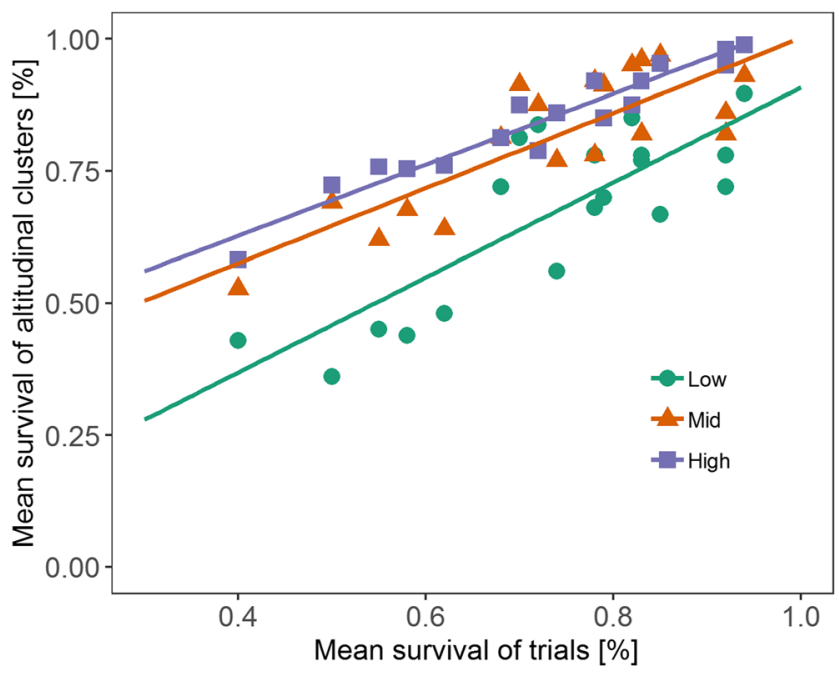

Fig. 4 Mean survival of provenances originating from different altitudinal clusters ( $y$-axis) plotted against mean survival rate of individual trials $(x$-axis). The three altitudinal clusters are: low $(0-$ $500 \mathrm{~m})$, mid (500-1000 m) and high (1000-1400 m)

provenance origin which were treated as random effects were found to be negligible (Table 2), while the tested early and late frosts indicators describe a substantial part of the observed variation in juvenile survival rate.

In general, the early and late frost variables had a stronger combined influence on juvenile survival rate compared to mean climatic factors such as summer xericity and continentality (Tables 2 and 3). Frost events during spring and autumn influenced the survival of juvenile Douglas-fir approximately to the same extent (Tables 2 and 3). The most decisive factors for survival where the total number of frost events in spring and autumn (LF1, and EF1), and the attributes that described the prevalence of warm spells before the extreme frost events. Such variables were the temperature difference between the extreme late frost date and the mean temperature of the 7 days prior (LF12), the number of vegetation days $>10^{\circ} \mathrm{C}$ before the extreme late frost date (LF8) during spring, and the number of vegetation days with $>5^{\circ} \mathrm{C}$ before the extreme early frost event in autumn (EF7) (Table 2, Fig. 3). These findings provide empirical evidence to the fact that not only the extreme minimum temperatures itself but also the magnitude of abrupt deviation from average temperatures affect tree survival (Katz and Brown 1992; Thornton et al. 2014). Other drivers such as summer xericity and continentality were also found to influence juvenile survival rate. Our finding of survival being rather positively affected by warmer and dryer conditions is surprising (Table 2), but could be explained by the absence of really strong summer droughts within the inventory periods and by otherwise favorable growing conditions correlated to warmer summer temperatures, and indeed, the 1970s and 1980s in which the majority of inventory periods' fall did not exhibit extreme summer droughts in Austria as found within later decades after 1990. The decline in survival as a response to continentality supports our finding that in sites with stronger alterations between warm and cold conditions, the effect of frost events can have more serious consequences.

Climate change-induced warming and lengthening of the growing season are likely to be accompanied by increased temperature variability, thus increasing the probability of occurrence of frost events outside of the actual winter season (Liu et al. 2018). Recent studies based on tree-ring analysis (Montwé et al. 2018) and remotely sensed phenological characteristics (Liu et al. 2018) also reported an increase in frost damage during spring and autumn if such events are preceded by warm weather. This result is particularly prominent in sites located in the east of Austria such as Pötsching $\left(47.763^{\circ} \mathrm{N}, 16.359^{\circ} \mathrm{E}\right.$, Fig. 9 in Annex) which experienced the strongest continental conditions (the difference between the mean temperature of the warmest and the coldest month is $\sim 20{ }^{\circ} \mathrm{C}$ ). During the whole

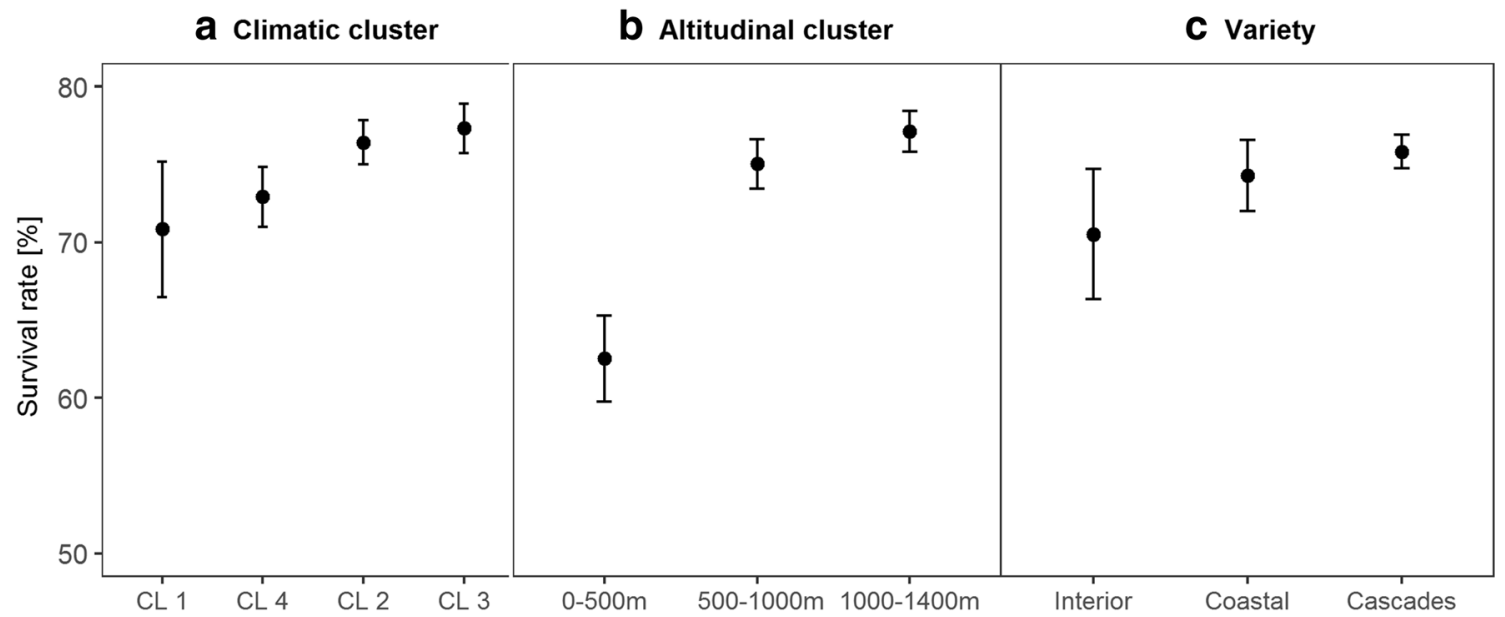

Fig. 5 Mean survival rate (black dots) and standard error (whiskers) of the three provenance origin attributes. Significant differences in survival rate were found in case of the altitudinal cluster only (see Table 2) 


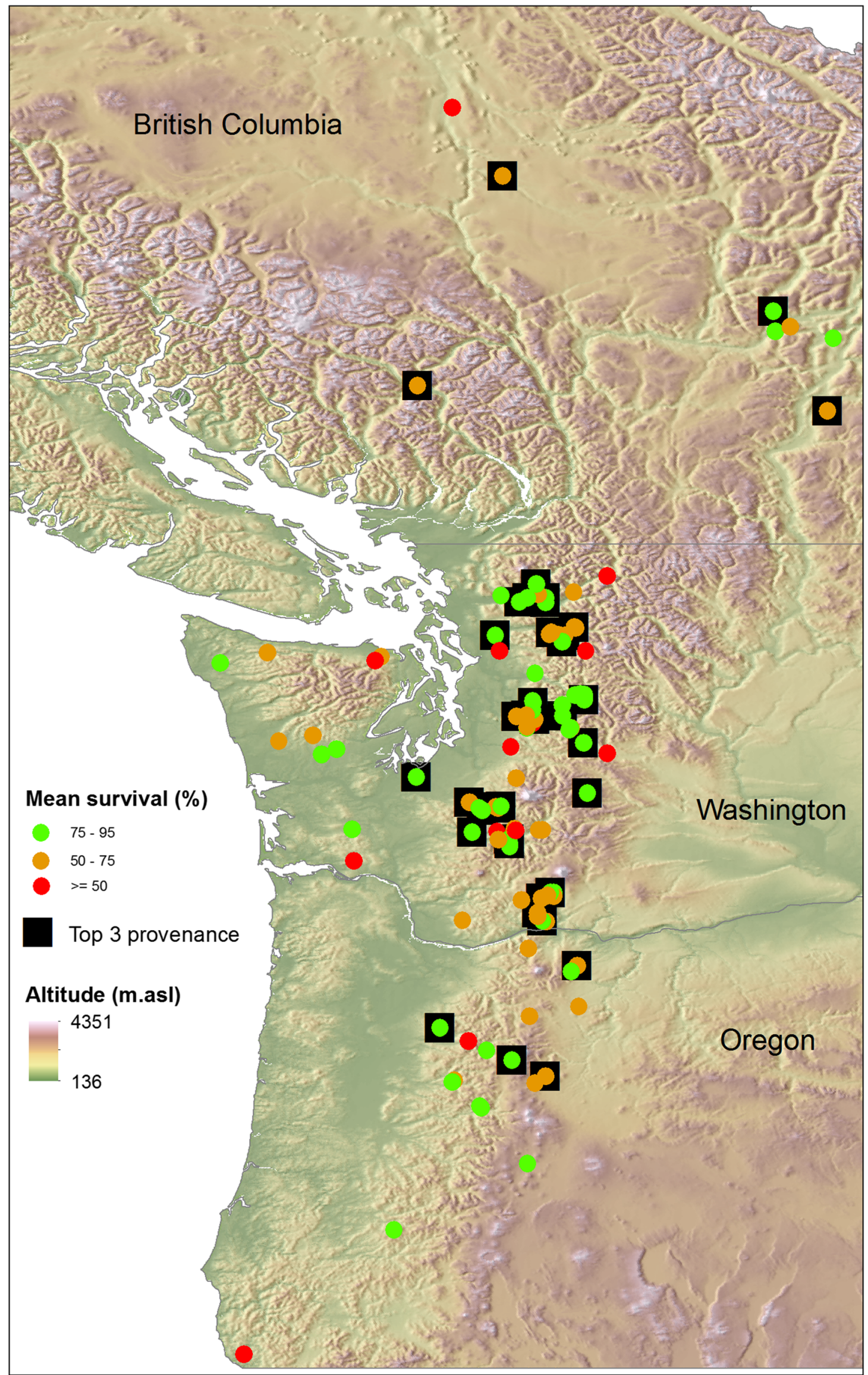

Q2 Springer 
Fig. 6 Locations of seed origin and mean survival of the tested provenances of Douglas-fir as calculated across all Austrian test sites. The provenances which ranked among top three in survival rate in Austria are depicted as black squares. In most sites in Austria, provenances from the Cascade region of Washington and Oregon ranked high in survival except for a few sites in the continental East of Austria where provenances from interior British Columbia were also among the top survivors. Top surviving provenances were mainly from an altitudinal range of $500-1400 \mathrm{~m}$ asl

inventory period (1973-1997), this site experienced warm conditions $\left(T_{\text {mean }}>10{ }^{\circ} \mathrm{C}\right)$ on an average of 46 days before an extreme late frost event in mid of May (1987) when $T_{\min }$ dropped to $-2.5{ }^{\circ} \mathrm{C}$. By that time, most trees are likely to have flushed, exposing them to severe frost damage. This trial is also one of the driest with mean warmest month temperature of $19{ }^{\circ} \mathrm{C}$ and mean summer precipitation of $330 \mathrm{~mm}$. Although conifers are known to tolerate extremely cold temperatures during winter, an abrupt drop in minimum temperature outside the winter can be detrimental for conifers (Glerum 1985).

Although the initial experience of planting Douglasfir in Central Europe revealed its susceptibility to frost (e.g., Larsen 1978; Schmiedel 1981; Braun and Wolf 2001), only a few of the Austrian sites analyzed in this study did suffer severe losses due to frost, while the overall mean survival rate was high $(\sim 74 \%$, Fig. 2$)$. This difference between several experimental studies and our field observations might be explained by the used methodologies: most contemporary studies examined the frost damage on plant tissues in controlled environments, which allows only a relative comparison of frost damages in the observed plant tissues and not an exact measure of mortality under field conditions. Moreover, controlled environments such as programmable freezers do not account for other factors such as shade, competition, and snow cover which modulates the sensitivity and amount of frost damage on exposed plant tissues (St Clair 2006; Bansal et al. 2015). Another reason may be that our trials might not have experienced extreme frost events during juvenile growth in such a magnitude that can cause severe mortality. Predicting occurrence of frost event is difficult and models predicting the response of the plants to frost with available gridded long-term average climate data may not be adequate (Bansal et al. 2015). In this study, we have used observed daily climate data to compute the biologically relevant frost climate variables that reflect weather conditions of and preceding frost events.

The trials used in the study cover a wide range of climatic conditions with some trials in the continental east of Austria. Here, they grow under climate conditions which are expected to be more frequent also in other locations in the near future (Kapeller et al. 2012). The high overall survival rate in the Austrian sites (Fig. 2), reveal that the provenances commonly planted in Austria and originating predominantly from the Cascades and coastal regions of Western North America (Fig. 1.B) are resilient enough to the frost events experienced till now and also likely in the future. The cascade and coastal provenances were also found to have superior productivity across a wide range of planting conditions and are expected to be the most productive in climate change across many regions in Europe (Chakraborty et al. 2015; Chakraborty et al. 2016). Genetic variation in frost damage and resistance have been studied extensively in North America (Emerson et al. 2006; St Clair 2006; Bansal et al. 2015) but rarely in Europe (but see; Lavadinović et al. 2013; Malmqvist et al. 2017). Phenology plays an important role in genetic variation in frost tolerance in temperate plants (Cooper et al. 2019). Interior provenances are likely to have less resistance against late frost in spring because they flush earlier than coastal provenances (St Clair 2006; Wolf 2012; Lavadinović et al. 2013; Bansal et al. 2015; Malmqvist et al. 2017). Coastal provenances, however, may exhibit higher sensitivity to early frost events in autumn because they need longer time for bud set and hardening (Aitken et al. 1996; Lavadinović et al. 2013; Malmqvist et al. 2017). We, however, did not find any evidence to this difference in spring and autumn frost sensitivity among Douglasfir provenances in our study, probably, because both early and late frost events play an equally important role in our regions. More precise phenological records will be required to test for the influence of phenology on intraspecific variation in frost tolerance. The weak influence of the random effects such as planting locations and provenance origin (Table 2), however, shows that our findings do not necessarily suffer from a lack of information on phenology. Our results are also contrary to the existing belief and some experimental evidence of higher frost damage in coastal and Cascade provenance of Douglas-fir if compared to the interior provenances (St Clair 2006; Bansal et al. 2015; Malmqvist et al. 2017) as we did not find a significant difference in survival rate between any of the provenance origin attributes except for altitude (Table 2, Fig. 4). Although this could be caused by the missing information on the exact reason for tree mortality, we believe that the relatively high goodness of fit of 59\% to $64 \%$ (Tables 2 and 3 ) and the negligible role of the random effects in the GLMM (Table 2) allows assigning a majority of the variation in survival to the occurrence of frost events and altitudinal level of seed provenance origin. Provenances originating from an altitude between 
500 and $1400 \mathrm{~m}$ were found to have optimum survival at majority of the trial locations (Fig. 4). However, care should be taken when transferring our conclusions to northern Europe or to the species native range in North America itself, as within these regions stronger evidence for provenance-specific frost sensitivity is documented (Bansal et al. 2015; Malmqvist et al. 2017), probably due to additional interaction between phenology, temperature development and photoperiod, which is less important in more southern Central Europe.

The study generates valuable evidence for adapting forests to climate change, especially for assisted migration whereby populations are facilitated to move to warmer locations in order to avoid likely maladaptation due to climate change. Our study shows that moving populations from colder North America to comparatively warmer Europe might expose the populations to frost risks especially in continental sites, a concern shared by many studies (Aitken and Whitlock 2013; BenitoGarzón et al. 2013; Schreiber et al. 2013; Aitken and Bemmels 2015; Bansal et al. 2015; Montwé et al. 2018). These risks can be avoided by careful selection of planting sites, site preparation, and to some extent by provenance selection especially selecting provenances from an altitudinal range of 500-1400 m. The relatively weak effect of provenance origin on frost tolerance and high mean survival rate of juvenile Douglas-fir may also indicate that Douglas-fir planted in Austria is adapted to the site-specific early and late frost events experienced till now. Therefore, the selection of the right planting material does not need to consider tradeoffs between frost tolerance and productivity because, under Austrian planting conditions, provenances from mid-elevation of the Cascades which are known to have superior productivity also show considerably high frost tolerance making Douglas-fir a suitable alternative tree species under climate change.

Acknowledgments We acknowledge the support of all present and former colleagues of BFW, Vienna who undertook field measurement at the Douglas-fir trials within the last four decades.

Funding information The study was funded by the Austrian Climate Research Program ACRP 4th Call for Proposals, Project no. B175092 (KR11AC0K00386).

Statement on data availability The datasets generated and/or analyzed during the current study are available in the Figshare repository (Chakraborty et al. 2018) at https://doi.org/10.6084/m9.figshare. 6632999.v2

\section{Compliance with ethical standards}

Conflict of interest The authors declare that they have no conflict of interest.

\section{Annex}

Fig. 7 Provenance clusters. The provenances planted in the Austrian trials were clustered into three provenance or seed origin attributes based on $\mathbf{A}$ variety of Douglas-fir, B altitude of provenance origin, $\mathbf{C}$ climate of provenance origin. The climatic cluster was based on PCA of all the 20 bioclimatic variables (see Table 1) of provenance origin and thereafter K-means clustering of the first three principal components into four groups
(A)

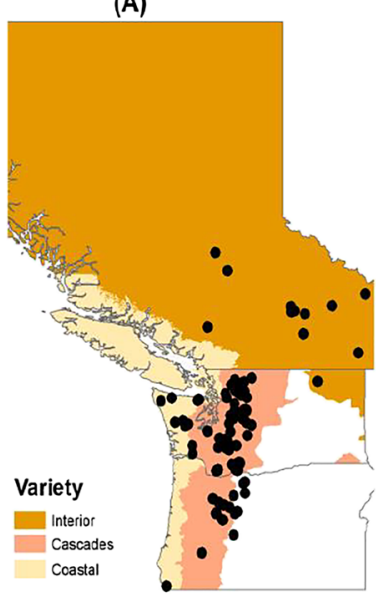

(B)

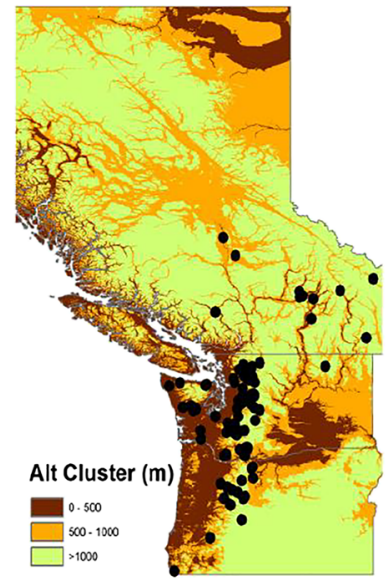

(C)

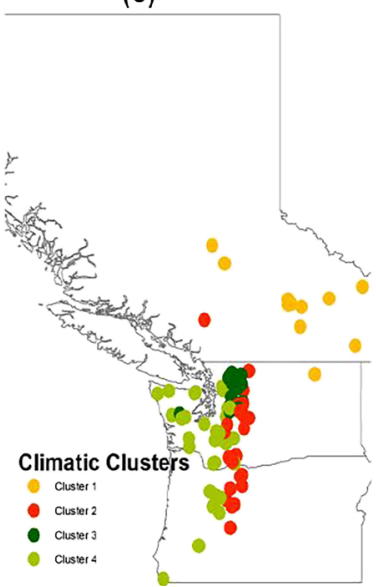




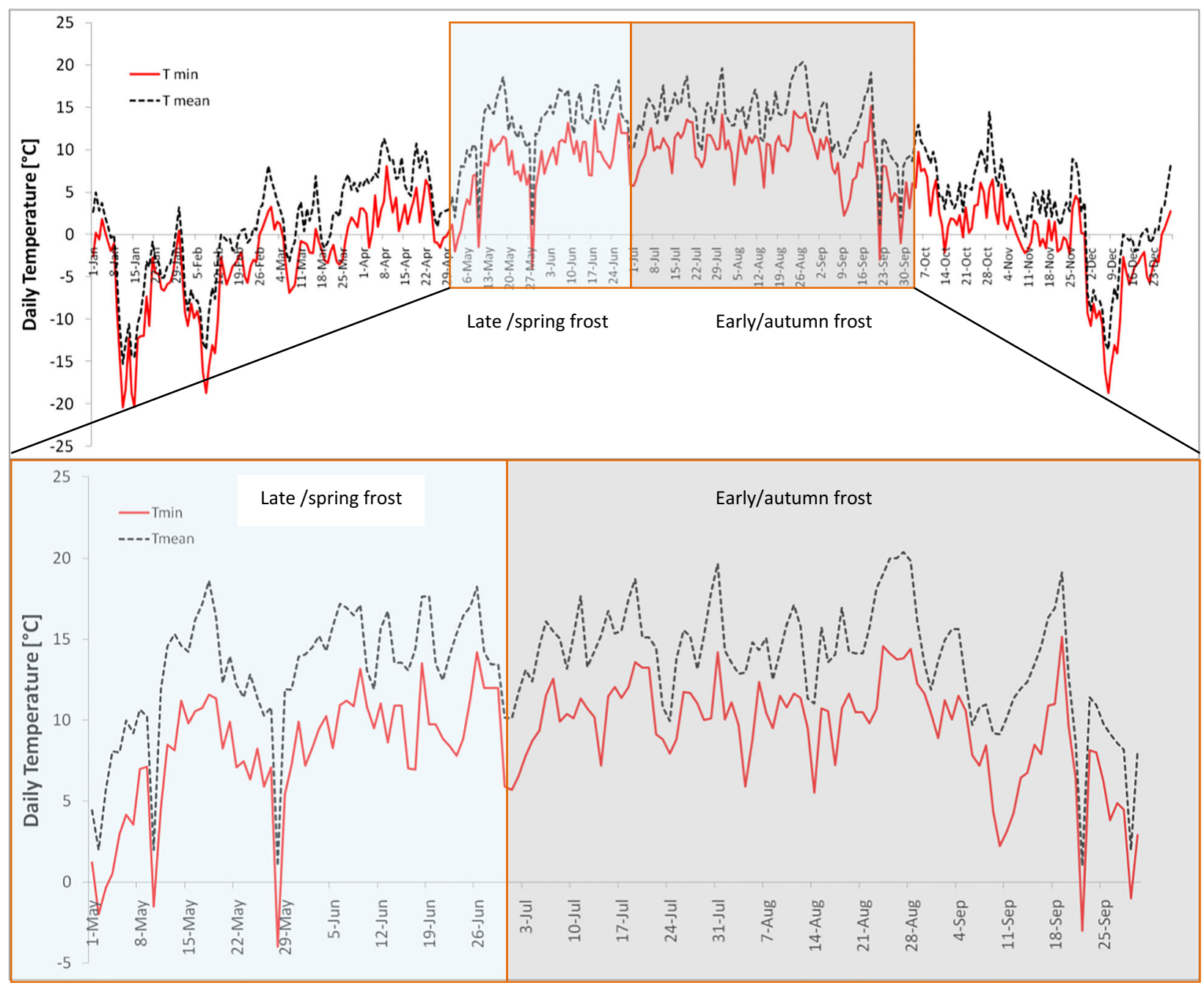

Fig. 8 Schematic example of the frost variables in a year over 10 years of inventory period. All variables were calculated with respect to an inventory period which refers time from to trial establishment till trial inventory at trial age of 10 years. Inventory period different in each trial because of their establishment dates. This is demonstrated as an example of a few late frost variables as given below. Late frost months = May and June. Early frost months $=$ July to Sep. LF1 $=$ Number of days with late frost events in the inventory period. There are 3 days with $\mathrm{Tmin}<0{ }^{\circ} \mathrm{C}$, so
$\mathrm{LF} 1=3 . \mathrm{LF} 3=$ Absolute minimum temperature of late frost events within the inventory period. 29 May has the lowest $T_{\min }$ of $-4{ }^{\circ} \mathrm{C}$, so LF3 =$4{ }^{\circ} \mathrm{C}$. $\mathrm{LF} 4=$ Mean temperature of the day on which the absolute minimum temperature (LF3) in the inventory period occurred. $T_{\text {mean }}$ on 29 May is $1{ }^{\circ} \mathrm{C}$, therefore $\mathrm{LF} 4=1{ }^{\circ} \mathrm{C}$. LF5 = Maximum number of late frost events within a single year of the inventory period, e.g., if two events occurred in $1966(-0.7,-1.2)$ and one in $1969(-3.4)$ than LF5 = 2 


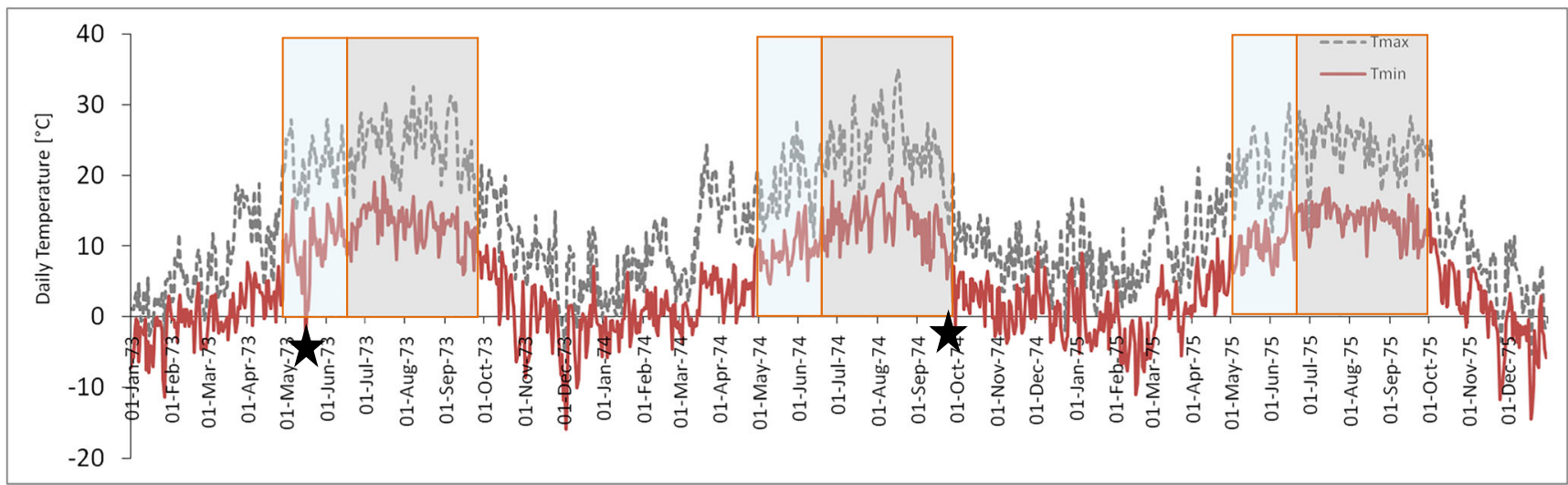

Fig. 9 Early and late frost events in Pötsching $\left(47.763^{\circ} \mathrm{N}, 16.359^{\circ} \mathrm{E}\right)$ in East of Austria which experiences strong continental conditions. During the inventory period covering 1973 to 1975 , the site experiences on late 16th of May 1973 where minimum temperature drops from 12 to $-2.5^{\circ} \mathrm{C}$ on a single day and an early frost event on 30 Sep where minimum temperature drops from 8 to $-1.2{ }^{\circ} \mathrm{C}$. Early (May-June) and late frost (July-Sep) are marked in blue and gray boxes, respectively. $\star$ Represents frost events during spring and autumn

Table 4 Provenance trials analyzed in this paper. The shaded cells represent the inventory period, i.e., the time from trial establishment until the latest survival assessment. The climate variables related to mean weather conditions and early and late frosts were calculated across these inventory periods

\begin{tabular}{|c|c|c|c|c|c|c|c|c|c|c|c|c|c|c|c|c|c|c|c|c|c|c|c|c|c|c|c|c|}
\hline \multirow[t]{2}{*}{ Trials } & \multirow[t]{2}{*}{ Lat $\left({ }^{\circ} \mathrm{N}\right)$} & \multirow[t]{2}{*}{$\operatorname{Lon}\left({ }^{\circ} \mathrm{E}\right)$} & \multirow[t]{2}{*}{ Alt (m.asl) } & \multicolumn{25}{|c|}{ Inventory period } \\
\hline & & & & 1973 & 1974 & 1975 & 1976 & $\mid 1977$ & 1978 & 1979 & 1980 & 1981 & $\mid 1982$ & \begin{tabular}{|c|}
1983 \\
\end{tabular} & \begin{tabular}{|c|}
1984 \\
\end{tabular} & 1985 & 1986 & \begin{tabular}{|c|}
1987 \\
\end{tabular} & \begin{tabular}{|c|}
1988 \\
\end{tabular} & 1989 & $\mid 1990$ & 1991 & 1992 & 1993 & \begin{tabular}{|l|l|}
3 & 1994 \\
\end{tabular} & 1995 & 1996 & 1997 \\
\hline Poettsching & 47.76397 & 16.35966 & 280 & & & & & & & & & & & & & & & & & & & & & & & & & \\
\hline Hochburg-Ach T.fl. 1 & 48.12736 & 12.89421 & 430 & & & & & & & & & & & & & & & & & & & & & & & & & \\
\hline Hochburg-Ach T.fl. 2 & 48.19888 & 12.93446 & 370 & & & & & & & & & & & & & & & & & & & & & & & & & \\
\hline Frankenburg & 48.0737 & 13.4088 & 620 & & & & & & & & & & & & & & & & & & & & & & & & & \\
\hline Buchschachen & 47.32601 & 16.11529 & 450 & & & & & & & & & & & & & & & & & & & & & & & & & \\
\hline Kumberg & 47.17815 & 15.51394 & 520 & & & & & & & & & & & & & & & & & & & & & & & & & \\
\hline Drassmarkt & 47.49476 & 16.40455 & 340 & & & & & & & & & & & & & & & & & & & & & & & & & \\
\hline Stronsdorf & 48.59015 & 16.31631 & 360 & & & & & & & & & & & & & & & & & & & & & & & & & \\
\hline Hallwang & 47.84606 & 13.0611 & 440 & & & & & & & & & & & & & & & & & & & & & & & & & \\
\hline Eberstein & 46.81457 & 14.60333 & 1080 & & & & & & & & & & & & & & & & & & & & & & & & & \\
\hline Loelling & 46.93662 & 14.59356 & 1300 & & & & & & & & & & & & & & & & & & & & & & & & & \\
\hline Techelsberg & 46.63823 & 14.06214 & 650 & & & & & & & & & & & & & & & & & & & & & & & & & \\
\hline Mattersburg & 47.68878 & 16.34817 & 600 & & & & & & & & & & & & & & & & & & & & & & & & & \\
\hline Gansbach & 48.33147 & 15.51247 & 540 & & & & & & & & & & & & & & & & & & & & & & & & & \\
\hline Ulmerfeld I & 48.00068 & 14.90605 & 580 & & & & & & & & & & & & & & & & & & & & & & & & & \\
\hline Rohrbach & 47.69727 & 16.44583 & 340 & & & & & & & & & & & & & & & & & & & & & & & & & \\
\hline Klausen-Leopoldsdorf & 48.07755 & 16.00267 & 430 & & & & & & & & & & & & & & & & & & & & & & & & & \\
\hline Goettweig/Kleinwien III & 48.3481 & 15.56204 & 520 & & & & & & & & & & & & & & & & & & & & & & & & & \\
\hline
\end{tabular}

\section{References}

Aitken SN, Bemmels JB (2015) Time to get moving: assisted gene flow of forest trees. Evol Appl 9(1):271-290

Aitken SN, Whitlock MC (2013) Assisted gene flow to facilitate local adaptation to climate change. Annu Rev Ecol Evol Syst 44:367-388

Aitken SN, Adams WT, Schermann N, Fuchigami LH (1996) Family variation for fall cold hardiness in two Washington populations of coastal Douglas-fir (Pseudotsuga menziesii var. menziesii (Mirb.) Franco). For Ecol Manag 80(1-3):187-195

Akaike H (1974) A new look at the statistical model identification. IEEE Trans Autom Control 19:716-723. https://doi.org/10.1109/TAC. 1974.1100705

Allen CD, Macalady AK, Chenchouni H, Bachelet D, McDowell N, Vennetier M, Kitzberger T, Rigling A, Breshears DD, Hogg EH(T), Gonzalez P, Fensham R, Zhang Z, Castro J, Demidova N, Lim JH, Allard G, Running SW, Semerci A, Cobb N (2010) A global overview of drought and heat-induced tree mortality reveals emerging climate change risks for forests. For Ecol Manag 259:660 684

Bansal S, St Clair JB, Harrington CA, Gould PJ (2015) Impact of climate change on cold hardiness of Douglas-fir (Pseudotsuga menziesii): environmental and genetic considerations. Glob Chang Biol 21(10): 3814-3826

Beck EH, Heim R, Hansen J (2004) Plant resistance to cold stress: mechanisms and environmental signals triggering frost hardening and dehardening. J Biosci 29:449-459

Benito-Garzón M, Ha-Duong M, Frascaria-Lacoste N, FernándezManjarrés J (2013) Habitat restoration and climate change: dealing with climate variability, incomplete data, and management decisions with tree translocations. Restor Ecol 21:530-536

Bolte A, Ammer C, Löf M, Madsen P, Nabuurs GJ, Schall P, Spathelf P, Rock J (2009) Adaptive forest management in Central Europe: climate change impacts, strategies and integrative concept. Scand J For Res 24:473-482

Braun H, Scheumann W (1989) Erste Ergebnisse der Prüfung von Douglasien-Bestandesnachkommenschaften unter besonderer Berücksichtigung der Frostresistenz. Beiträge Forstwirtschaft 23:4-11

Braun H, Wolf H (2001) Untersuchungen zu Wachstum und Frosthärte von Douglasien-Populationen in Ostdeutschland. Beitr Forstwirtsch u Landschaft Ökol 35:211-214

Breiman L (2001) Random forests. Mach Learn 45:5-32

Chakraborty D, Wang T, Andre K, Konnert M, Lexer MJ, Matulla C, Schueler S (2015) Selecting populations for non-analogous climate 
conditions using universal response functions: the case of Douglasfir in Central Europe. PLoS One 10:e0136357

Chakraborty D, Wang T, Andre K et al (2016) Adapting Douglas-fir forestry in Central Europe: evaluation, application, and uncertainty analysis of a genetically based model. Eur J For Res 1-18

Chakraborty D, Matulla C, Andre K, Weissenbacher L, Schueler S (2018) Response of Douglas fir provenances to spring and autumn frost in Austria. V2. Figshare. [dataset]. https://doi.org/10.6084/m9. figshare.6632999.v2

Coder KD, Biology T, Care H (2011) Trees \& cold temperatures. 7912: WSFNR-17-08 February 2017

Cooper HF, Grady KC, Cowan JA, Best RJ, Allan GJ, Whitham TG (2019) Genotypic variation in phenological plasticity: reciprocal common gardens reveal adaptive responses to warmer springs but not to fall frost. Glob Chang Biol 25:187-200

Cruickshank MG (2017) Climate and site factors affecting survival and yield of Douglas-fir in the cedar-hemlock ecosystem of the southern interior of British Columbia. Forestry 90:219-233

Day WR, Chrystal RN (1928) Damage by late frost on Douglas fir, Sitka spruce, and other conifers. Forestry 2:19-30

Emerson JL, Frampton J, McKeand SE (2006) Genetic variation of spring frost damage in 3-year-old Fraser fir christmas tree plantations. HortScience 41:1531-1536

Foster RE, Johnson LS (1963) The significance of root rot and frost damage in some Douglas fir plantations. For Chron 39:266-272

$\mathrm{Fu}$ YH, Piao S, Op de Beeck M et al (2014) Recent spring phenology shifts in western Central Europe based on multiscale observations. Glob Ecol Biogeogr 23:1255-1263

Glerum C (1985) Frost hardiness of coniferous seedlings: principles and applications. Eval Seedl Qual Princ Proced Predict Abil major tests $107-123$

Hanewinkel M, Cullmann DA, Schelhaas M-J et al (2013) Climate change may cause severe loss in the economic value of European forest land. Nat Clim Chang 3:203-207

He F, Duncan P (2000) Density-dependent effects on tree survival in an old- growth Douglas fir forest. J Ecol 88:676-688

IPCC (2013) Working group I contribution to the IPCC fifth assessment report, climate change 2013: the physical science basis. IPCC AR5: 2014

Isaac-Renton MG, Roberts DR, Hamann A, Spiecker H (2014) Douglasfir plantations in Europe: a retrospective test of assisted migration to address climate change. Glob Chang Biol 20:2607-2617

Kapeller S, Lexer MJ, Geburek T, Hiebl J, Schueler S (2012) Intraspecific variation in climate response of Norway spruce in the eastern alpine range: selecting appropriate provenances for future climate. For Ecol Manag 271:46-57

Katz RW, Brown BG (1992) Extreme events in a changing climate: variability is more important than averages. Clim Chang 21:289-302

Klimo E, Hager H (eds) (2000) Spruce monocultures in Central Europe problems and prospects. Proceedings 33, European Forest Institute. 8 ISBN: 952-9844-76-X, ISSN: 1237-8801

Kölling C (2008) Die Douglasie im Klimawandel: Gegenwärtige und zukünftige Anbaubedingungen in Bayern. LWF Wissen 12-21

Konnert M, Ruetz W (2006) Genetic aspects of artificial regeneration of Douglas-fir (Pseudotsuga menziesii) in Bavaria. Eur J For Res 125: 261-270

Kreyling J, Buhk C, Backhaus S, Hallinger M, Huber G, Huber L, Jentsch A, Konnert M, Thiel D, Wilmking M, Beierkuhnlein C (2014) Local adaptations to frost in marginal and central populations of the dominant forest tree Fagus sylvatica L. as affected by temperature and extreme drought in common garden experiments. Ecol Evol 4:594605

Kreyling J, Schmid S, Aas G (2015) Cold tolerance of tree species is related to the climate of their native ranges. J Biogeogr 42:156-166

Larsen JB (1978) Die Frostresistenz von 60 verschiedenen DouglasienHerkünften sowie über den Einfluss der Nährstoffversorgung auf die
Frostresistenz der Douglasie. In: Larsen BJ, Muhle O, Lohbeck H (Hrsg) Untersuchungen zur Bestandesbegründung der Douglasie. Sauerländer's Verlag, Frankfurt am Main, pp 1-126

Lavadinović V, Isajev V, Rakonjac L et al (2013) Douglas-fir provenance phenology observations. Ekol Bratislava 32(4):376-382

Lindner M, Maroschek M, Netherer S, Kremer A, Barbati A, GarciaGonzalo J, Seidl R, Delzon S, Corona P, Kolström M, Lexer MJ, Marchetti M (2010) Climate change impacts, adaptive capacity, and vulnerability of European forest ecosystems. For Ecol Manag 259: 698-709

Liu Q, Piao S, Janssens IA et al (2018) Extension of the growing season increases vegetation exposure to frost. Nat Commun 9:426

Lumley T (2009) Leaps: regression subset selection. Compr R Arch Netw

Maechler M, Struyf A, Hubert M et al (2015) Package 'cluster' R Top Doc. doi: ISBN 0-387-95457-0

Malmqvist C, Wallin E, Lindström A, Säll H (2017) Differences in bud burst timing and bud freezing tolerance among interior and coastal seed sources of Douglas fir. Trees - Struct Funct 31:1987-1998

Montwé D, Isaac-Renton M, Hamann A, Spiecker H (2018) Cold adaptation recorded in tree rings highlights risks associated with climate change and assisted migration. Nat Commun 9:1574

Muller-Landau HC, Condit RS, Chave J, Thomas SC, Bohlman SA, Bunyavejchewin S, Davies S, Foster R, Gunatilleke S, Gunatilleke N, Harms KE, Hart T, Hubbell SP, Itoh A, Kassim AR, LaFrankie JV, Lee HS, Losos E, Makana JR, Ohkubo T, Sukumar R, Sun IF, Nur Supardi MN, Tan S, Thompson J, Valencia R, Munoz GV, Wills C, Yamakura T, Chuyong G, Dattaraja HS, Esufali S, Hall P, Hernandez C, Kenfack D, Kiratiprayoon S, Suresh HS, Thomas D, Vallejo MI, Ashton P (2006) Testing metabolic ecology theory for allometric scaling of tree size, growth and mortality in tropical forests. Ecol Lett 9:575-588

Neumann M, Mues V, Moreno A, Hasenauer H, Seidl R (2017) Climate variability drives recent tree mortality in Europe. Glob Chang Biol 23:4788-4797

O'Neill GA, Adams WT, Aitken SN (2001) Quantitative genetics of spring and fall cold hardiness in seedlings from two Oregon populations of coastal Douglas-fir. For Ecol Manag 149:305-318

Petkova K (2011) Investigation of Douglas-fir provenance test in northwestern Bulgaria at age 24 years. 60(7):288-296

R Core Team (2013) R Core Team. R A lang environ stat comput R found stat comput Vienna, Austria ISBN 3-900051-07-0, URL http:// www.R-project.org/

Rehfeldt GE, Jaquish BC, López-Upton J et al (2014) Comparative genetic responses to climate in the varieties of Pinus ponderosa and Pseudotsuga menziesii: reforestation. For Ecol Manag 324:147-157

Reyer C, Lasch-Born P, Suckow F, Gutsch M, Murawski A, Pilz T (2014) Projections of regional changes in forest net primary productivity for different tree species in Europe driven by climate change and carbon dioxide. Ann For Sci 71:211-225

Sakai A, Weiser CJ (1973) Freezing resistance of trees in North America with reference to tree regions. Ecology 54:118-126

Scheifinger H, Menzel A, Koch E, Peter C (2003) Trends of spring time frost events and phenological dates in Central Europe. Theor Appl Climatol 74:41-51

Schmiedel H (1981) Zum Anbau frostresistenter Douglasien. Beiträge Forstwirtschaft 15:138-141

Schreiber SG, Ding C, Hamann A, Hacke UG, Thomas BR, Brouard JS (2013) Frost hardiness vs. growth performance in trembling aspen: an experimental test of assisted migration. J Appl Ecol 50:939-949

Schueler S, Liesebach M (2014) Latitudinal population transfer reduces temperature sum requirements for bud burst of European beech. Plant Ecol 216:111-122. https://doi.org/10. 1007/s11258-014-0420-1

Schultze U, Raschka HD (2002) Douglasienherkünfte für den "Sommerwarmen Osten" Österreichs. Ergebnisse aus DouglasienHerkunftsversuchen des Institutes für Forstgenetik FBVA-Wien 
FBVA-Berichte Nr. 126 - 2002 ISSN 1013-0713 "Douglas -fir provenances for summerwarm Austria: results from Douglas-fir Provenace trians in Institute of Forest genetics: BFW, Vienna" (http://bfw.ac.at/rz/bfwcms.web_print?dok=5632)

Seidl R, Schelhaas MJ, Lexer MJ (2011) Unraveling the drivers of intensifying forest disturbance regimes in Europe. Glob Chang Biol 17: 2842-2852

Seidl R, Thom D, Kautz M, Martin-Benito D, Peltoniemi M, Vacchiano G, Wild J, Ascoli D, Petr M, Honkaniemi J, Lexer MJ, Trotsiuk V, Mairota P, Svoboda M, Fabrika M, Nagel TA, Reyer CPO (2017) Forest disturbances under climate change. Nat Clim Chang 7:395402

Senf C, Pflugmacher D, Zhiqiang Y, Sebald J, Knorn J, Neumann M, Hostert P, Seidl R (2018) Canopy mortality has doubled in Europe's temperate forests over the last three decades. Nat Commun 9:4978

Simpson DG (1990) Frost hardiness, root growth capacity, and field performance relationships in interior spruce, lodgepole pine, Douglasfir, and western hemlock seedlings. Can J For Res 20:566-572

Spiecker H, Mielikäinen K, Köhl M, Skovsgaard JP (2012) Growth trends in European forests: studies from 12 countries. Springer, Berlin Heidelberg

St Clair JB (2006) Genetic variation in fall cold hardiness in coastal Douglas-fir in western Oregon and Washington. Can J Bot Can Bot 84:1110-1121
Stevenson JF, Hawkins BJ, Woods JH (1999) Spring and fall cold hardiness in wild and selected seed sources of coastal Douglas-fir. Silvae Genet 48:29-34

Strimbeck GR, Schaberg PG, Fossdal CG et al (2015) Extreme low temperature tolerance in woody plants. Front Plant Sci 6:884

Sychra D, Mauer O (2013) Prosperity of Douglas fir (Pseudotsuga menziesii [mirb.] franco) plantations in relation to the shelter. J For Sci 59:352-358

Thornton PK, Ericksen PJ, Herrero M, Challinor AJ (2014) Climate variability and vulnerability to climate change: a review. Glob Chang Biol 20:3313-3328

Van Mantgem PJ, Stephenson NL, Byrne JC et al (2009) Widespread increase of tree mortality rates in the Western United States. Science 323:521-524. https://doi.org/10.1126/science.1165000

Wang T, Hamann A, Spittlehouse DL, Murdock TQ (2012) ClimateWNA - high-resolution spatial climate data for Western North America. J Appl Meteorol Climatol 51:16-29

Westerling AL, Hidalgo HG, Cayan DR, Swetnam TW (2006) Warming and earlier spring increase Western U.S. forest wildfire activity. Science 313:940-943. https://doi.org/10.1126/science.1128834

Publisher's note Springer Nature remains neutral with regard to jurisdictional claims in published maps and institutional affiliations. 